\title{
Investigation of the Effects of Game Supported Rehabilitation Program on Motor and Cognitive Skills in a Patient with Co-occurrence of Multiple Sclerosis and Parkinson's Disease: A Case Report
}

\author{
Multipl Skleroz ve Parkinson Hastalı̆̆ı Birlikteliği Görülen Hastada Oyun Destekli \\ Rehabilitasyon Programının Motor ve Kognitif Beceriler Üzerine Etkilerinin İncelenmesi: \\ Bir Olgu Sunumu
}

\begin{abstract}
Multiple sclerosis (MS) and Parkinson's disease (PD) are progressive central nervous system diseases that cause significant activity limitation and participation restrictions by causing motor and non-motor symptoms in patients. With this case report, we aimed to present the effects of the game-supported rehabilitation in a patient with co-occurrences of MS and PD that we rarely encounter. A 54-year-old female patient with co-occurrence of MS and PD who was mobilized with a wheelchair was evaluated as a case. The patient was treated for 1 hour, 3 days a week for 8 weeks. After a 30-minute neurophysiologic exercise program, the patient was taken to 30-minute game therapy using the "Smart Physiotherapy Game System (USE-IT)". USE-IT, a game console developed in line with our clinical experience, is also a TUBITAK 1512 project. On the game console, the patient played six games using different grip materials. Before and after the treatment, diseases levels and findings were evaluated using the expanded disability status scale, the modified Hoehn and Yahr scale, and the unified PD rating scale. Frequency of falling was asked to the patient and relatives, rigidity was determined using manual evaluations, muscle strength was assessed through gross muscle strength assessment, cognitive status was evaluated using the Montreal cognitive assessment scale, posture was evaluated with New York posture rating scale, manual skills were evaluated with the Minnesota manual dexterity test, and fatigue was evaluated with fatigue impact scale. Functional condition was evaluated using the functional independence measurement and quality of life was evaluated with MS quality of life questionnaire and PD questionnaire. As a result, it is seen that there are clinically significant improvements in the severity of disease, fatigue, falling, postural disorders, manual skills, physical, cognitive and emotional state, mobility, activities of daily living and quality of life of the patient.
\end{abstract}

Keywords: Multiple sclerosis, Parkinson's disease, rehabilitation, virtual reality, game therapy

$\ddot{O} \mathbf{z}$

Multipl skleroz (MS) ve Parkinson hastalı̆̆ $(\mathrm{PH})$, motor ve non-motor semptomlara sebep olarak hastalarda önemli derecede aktivite limitasyonu ve katılım kısıtlılıkları yaratan progresif merkezi sinir sistemi hastalıklarıdır. Olgu raporu ile nadiren karşılaştığımız MS ve PH birlikteliğine sahip hastada oyun destekli rehabilitasyonun olumlu etkilerini sunmayı amaçladık. MS ve PH birlikteliğine sahip tekerlekli sandalye ile mobilizasyonu sağlanan 54 yaşındaki kadın hasta olgu olarak incelendi. Hasta 8 hafta süreyle haftada 3 gün 1'er saat olmak üzere tedaviye alınmıştır. Hasta 30 dakika nörofizyolojik egzersiz programı sonrasında "Akıllı Fizyoterapi Oyun Sistemi (USE-IT)” ile 30 dakika oyun tedavisine alındı. Klinik tecrübelerimiz doğrultusunda geliştirilmiş bir oyun konsolu olan USE-IT aynı zamanda bir TÜBİTAK 1512 projesidir. Oyun konsolunda hasta farklı kavrama malzemeleri kullanarak altı oyun oynadı. Tedavi öncesi ve sonrası hastalıkların seviyeleri ve bulguları, genişletilmiş durum özürlülük skalası, modifiye Hoehn ve Yahr skalası ve birleşik PH derecelendirme ölçeği ile, düşme frekansı hasta ve yakınına sorularak, rijiditesi manuel değerlendirmeler ile, kas kuvveti kaba kas kuvvetleri değerlendirmesi ile, kognitif durumu Montreal bilişsel değerlendirme ölçeği ile, postürü New York postür değerlendirme ölçeği ile, el becerileri Minnesota el beceri testi ile, yorgunluğu yorgunluk etki ölçeği ile, fonksiyonel durumu fonksiyonel bağımsızlık ölçeği ile ve yaşam kalitesi MS yaşam kalitesi anketi ve PH anketi ile değerlendirilmiştir. Sonuç olarak, hastanın hastalık şiddetinde, yorgunluk, düşme ve postüral bozukluklarında, el becerilerinde, fiziksel, kognitif ve emosyonel durumunda, mobilitesinde, günlük yaşam aktivitelerinde, ve yaşam kalitesinde klinik olarak anlamlı gelişmeler olduğu görülmektedir.

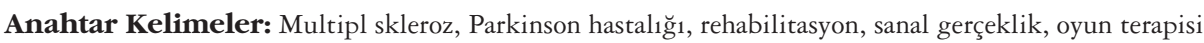

Address for Correspondence/Yazışma Adresi: Gülşah Sütçü MSc, Hacettepe University Faculty of Physical Therapy and Rehabilitation,

Department of Neurological Rehabilitation, Ankara, Turkey

Phone: +90 5547734223 E-mail: gulsahsutcu92@gmail.com ORCID: orcid.org/0000-0002-8457-7477

Received/Geliş Tarihi: 01.05.2020 Accepted/Kabul Tarihi: 02.11 .2020

${ }^{\circ}$ Copyright 2021 by Turkish Neurological Society

Turkish Journal of Neurology published by Galenos Publishing House. 


\section{Introduction}

Parkinson's disease (PD) is a progressive and neurodegenerative movement disorder caused by the effects of nigrostriatal dopaminergic pathways in the basal ganglia. Although its etiology is not fully known, environmental and genetic factors are thought to be effective in the emergence of the disease. Akinesia, postural instability, tremor, and rigidity are known as cardinal manifestations of the disease (1).

Multiple sclerosis (MS) is a chronic inflammatory and autoimmune disease characterized by perivascular infiltration of mononuclear cells, demyelination, axonal loss, and gliosis in the central nervous system. Demyelination plates formed in the brain and medulla spinalis cause motor, sensory, and cognitive symptoms such as functional loss, fatigue, sensory and cognitive problems, pain and depression (2).

In patients with progressive neurologic diseases such as PD and MS, besides medical treatment, physical therapy and rehabilitation approaches are extremely important in maintaining functional independence and quality of life. Starting rehabilitation as early as possible after the diagnosis process of individuals with neurologic diseases plays an important role, especially in maintaining basic mobility activities such as standing and walking. When the literature is examined, it is seen that there are many studies in different areas of rehabilitation such as different types of exercise, orthosis, electrotherapy, and cognitive therapy in individuals with different neurologic diseases such as PD, MS, stroke and muscle diseases. Also, technology-assisted rehabilitation programs have become popular in recent years. Many studies are showing the effects of virtual reality or game-assisted rehabilitation in neurologic patients in terms of physical and cognitive aspects $(3,4)$. The strangest parts of many of the studies examining the effects of game-assisted rehabilitation are that patients with different functional levels play games at similar levels of difficulty and games are not related to daily life activities. The reason for this is that most game scenarios are written for healthy individuals. However, we think that games that are designed according to the functional levels of the patients and include daily life activities are more suitable for the physical and cognitive development of patients. For successful rehabilitation, it is extremely important to evaluate the functional capacities of patients with a game before playing the games in the clinic and to plan other games according to the functional levels of the patients using a computer program. It is thought that the game scenarios written by physicians who play an active role in rehabilitation according to daily life activities and different movement patterns of the upper extremities will play an important role in the recovery of functions. Also, unlike other games, the use of gripping materials such as a sponge, hose or drumstick can be used to increase the sensory development and grip of the patient in games whose scenarios are created in accordance with daily life activities.

When the literature is reviewed, there is no study showing the effectiveness of rehabilitation because the co-occurrence of MS and PD is rarely seen in the clinic. The aim of this case report was to demonstrate the effectiveness of individually planned gamesupported rehabilitation approaches in a patient with co-occurring MS and PD.

\section{Case Report}

\section{Method}

This case report was conducted between March-May 2019 in the Hacettepe University Faculty of Physical Therapy and Rehabilitation, Neurological Rehabilitation Unit. A 54-year-old female patient who was diagnosed as having PD 11 years after receiving her MS diagnosis was included in the case report. The patient and relatives were informed about the case report and written consent was obtained before starting. The patient was taken to the physiotherapy and rehabilitation program 3 days per week for 8 weeks, 1 hour per day. The physiotherapy and rehabilitation program was created from neurophysiologic exercises prepared specifically for the individual considering the patient's evaluations and using functional strength training, stretching exercises, balance-coordination and walking exercises and sensory stimuli. With the neurophysiologic exercise program, the patient was given virtual reality-based game therapy on the touch screen. To examine the effectiveness of the exercise program, the patient was evaluated in detail for PD and MS before and after treatment.

\section{Expanded Disability Status Scale (EDSS)}

The EDDS is widely used to evaluate the level of disability in patients with MS. On this scale, the patient receives a score between 0-10 in terms of pyramidal, cerebellar, brain stem, sensory, bowel-bladder, visual, mental and other functions. High scores indicate an increased level of disability (5).

\section{Modified Hoehn and Yahr Scale}

Modified Hoehn and Yahr scale, which is a simple staging classification scores between 0 and 5 regarding the motor symptoms of $\mathrm{PD}$, is used to demonstrate the degree of progression and to combine the characteristics of motor disorder and disability (6).

\section{Evaluation of Frequency of Falling}

The frequency of falling was evaluated by asking the patient and their relatives how many times the patient fell within 1 week.

\section{Rigidity Assessment}

In joints with rigidity, the rigidity was manually evaluated and graded as mild-moderate-severe (7).

\section{Evaluation of Muscle Strength}

Gross muscle strength is evaluated as strong-moderate and weak, with the completion of flexion, extension, abduction and adduction movements of the upper and lower extremities against the resistance given by the physician (8).

\section{Cognitive Status Assessment}

Montreal cognitive assessment (MoCA) was used for cognitive status assessment. MoCA evaluates different cognitive abilities, including executive functions, visual-spatial skills, memory, language, attention and concentration, abstract thinking, computation and orientation (9).

\section{Posture Evaluation}

The New York posture rating scale was used to evaluate the postures of the patients. In this scale, postural changes that can 
occur in 13 different parts of the head, shoulders, spine, abdomen, back, hips and feet are scored by observing the posterior and lateral of the person and performing posture analysis (10).

\section{Evaluation of PD Severity and Findings}

The unified PD rating scale (UPDRS), which is one of the most widely accepted scales used in the evaluation and follow-up of PD, was used to evaluate disease severity and symptoms. The UPDRS includes four subtitles and 42 items. Subtitles consist of mentation, behavior and mood, activities of daily living, motor examination and treatment complications. High scores indicate severe symptoms or finding (11).

\section{Fatigue Evaluation}

The fatigue impact scale was used to evaluate the symptoms of fatigue and their effects on daily life. This scale consists of 40 items related to the cognitive, physical and psychosocial effects of fatigue. Each item is scored between 0-4 points. Cognitive effect and physical effect are scored over 0-40 and psychosocial effect is scored over $0-80$ points. High scores show the effect of high fatigue (12).

\section{Evaluation of Functional Independence}

Functional independence measurement (FIM) was used to evaluate the individual's level of functional independence in daily life. FIM consists of six functional subsections that include self-care, sphincter control, mobility/transfer, locomotion, communication and social cognition. In the evaluation, each item is scored between 1-7 points according to the amount of help received by the patient. The total score ranges from 18 to 126 . High scores indicate that functional independence is low and the need for help is high (13).

\section{Evaluation of Quality of Life}

\section{Evaluation of Quality of Life in PD}

The PD questionnaire-39 (PDQ-39) was used to assess the quality of life in PD. The PDQ-39 consists of 39 questions related to mobility, activities of daily living, emotional well-being, stigma, social support, cognition, communication and bodily discomfort. A high score indicates a low quality of life (14).

\section{Evaluation of Quality of Life in MS}

The quality of life in terms of MS was evaluated with the MS quality of life- 54 questionnaire. The questionnaire consists of 54 questions related to physical function, physical role limitations, emotional role limitations, pain, emotional well-being, energy/ fatigue, health perceptions, social function, cognitive function, health problems, quality of life, sexual function. High scores show a high quality of life (15).

\section{Evaluation of Manual Skills}

The Minnesota manual dexterity test (MMDT) was used to evaluate manual skills. The MMDT is a functional dexterity test that evaluates manual skills with time and is used frequently in older and neurologic patient groups. In the MMDT, the right and left manual skills of individuals are evaluated with the ability to place, remove, turn, and place 60 stamps by keeping time (16).

\section{Rehabilitation}

The patient was given an exercise program within the scope of the technology-supported Bobath concept for MS and PD including:
- Stretching and strengthening exercises in the bed,

- Trunk training, functional strengthening and coordination exercises in sitting positions,

- Weight transfer and balance exercises of standing position,

- Balance and walking training in a parallel bar,

- The Smart Physiotherapy Game System (Upper Extremity Smart Exercises-Innovative Treatment; USE-IT) is a TUBITAK supported touchscreen game console project that we developed in the Hacettepe University Faculty of Physical Therapy and Rehabilitation, Neurological Rehabilitation Unit. The scenarios of the games (abacus, balloon popping, doorman, plumber, matching, drumming, and car washing games) on this game console were written by us to include motion patterns suitable for patients in line with daily life activities. The games are designed to develop functional activities suitable for upper limb motion patterns (opposition, pronation-supination, wrist-elbow and shoulder flexion-extension, shoulder abduction-adduction and internalexternal rotation) and to increase stabilization. In addition, different grip materials such as a sponge, hose or drumstick are used in games in accordance with daily life activities. The visuals of the games are shown in Figure 1. To determine the functional status of the patient, the game "Balloon Popping" was played before each treatment session. With this game, the patient is requested to pop the balloons that appear on different parts of the touch screen as quickly as possible and by touching the middle of the balloon. The upper extremity functional skill status of the patient was determined by the patented software with the map that we define as "limitation map". Accordingly, the games were automatically planned by the software in accordance with the current individual functional capacity. With this map, the system enables the patient to play the game in a way that will make more repetitions in areas with the potential for development.

\section{Results}

The demographic and clinical features of a 54-year-old female patient with MS and PD are shown in Table 1.

When the clinical evaluation results before and after the treatment are examined, it was observed that there was a decrease in disease severity and symptoms, the number of falls, the severity of rigidity, postural disorders, and fatigue severity. In addition, an increase was observed in the strength of the lower and upper extremity muscles, cognitive functions, independence levels in daily life activities, quality of life, and manual skills. The results of the clinical evaluation are shown in Table 2.

\section{Discussion}

When the results of our case report were examined, it was seen that game-supported rehabilitation approaches had positive effects on disease severity, fatigue, falling, manual skills, physical, cognitive and emotional status, daily life activities and quality of life in a patient with co-occurring MS and PD. When the literature is examined, studies are showing the effectiveness of physical therapy and rehabilitation programs in MS or PD. However, no study demonstrating the effectiveness of rehabilitation was found in the co-occurrence of MS and PD. Moreover, the physical and cognitive findings and prognosis of the disease are more severe in patients with co-occurring MS and PD compared with individuals with a single neurologic disease. Our case report revealed the 

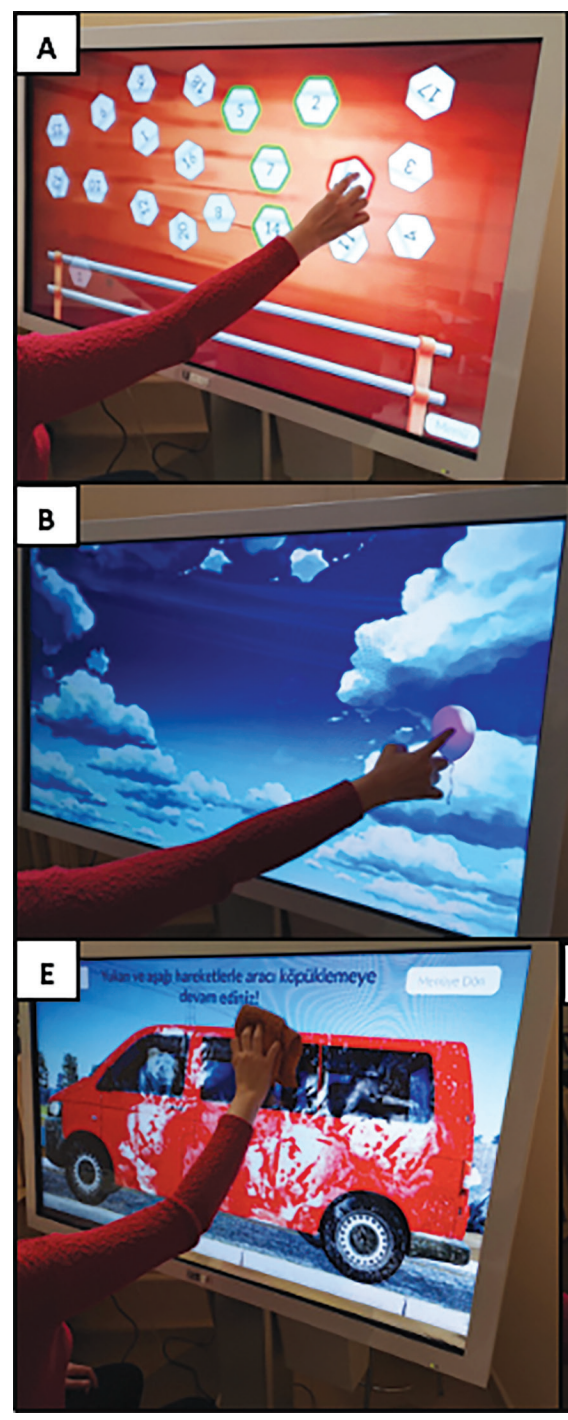
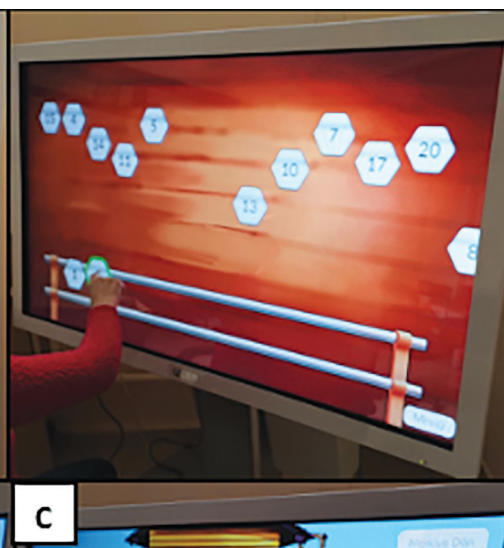

C

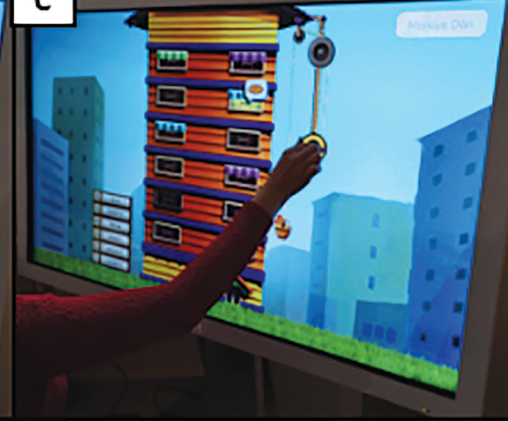

$\mathbf{F}$

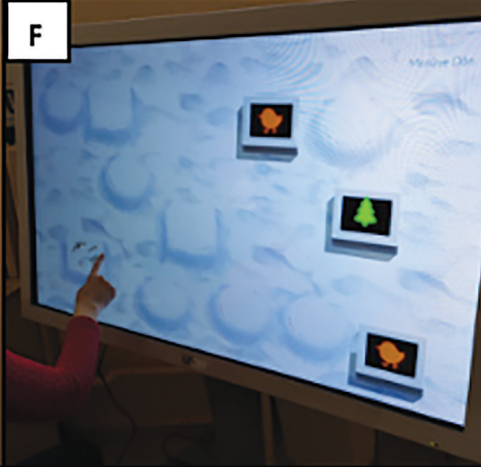

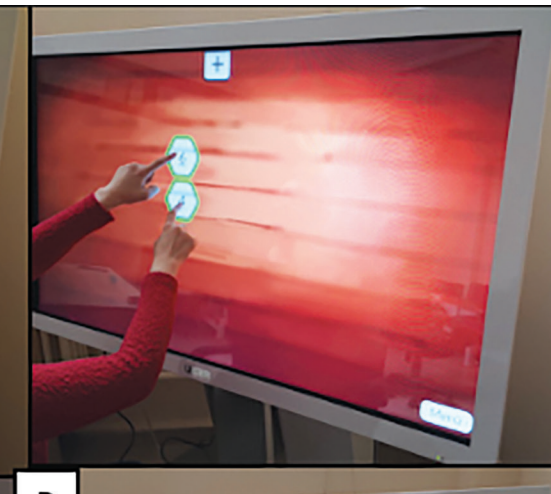

D
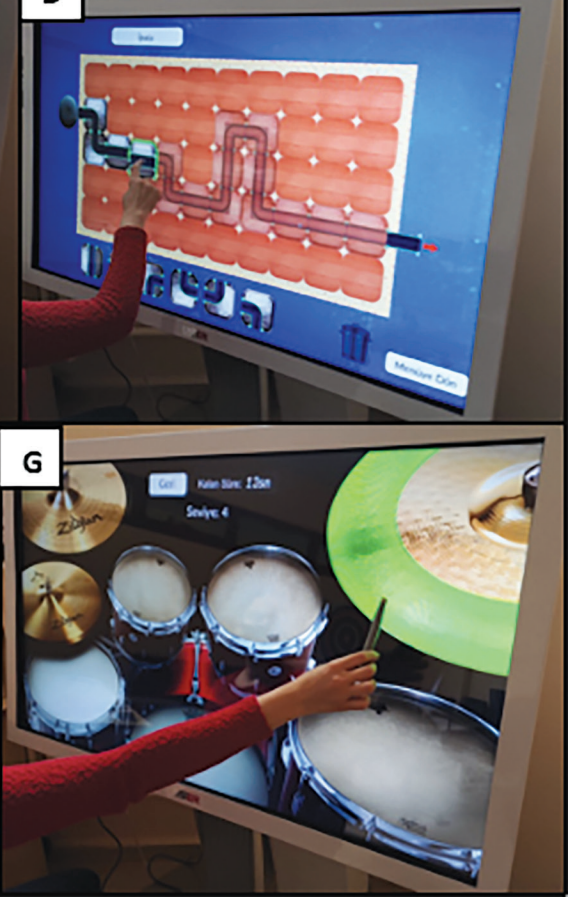

Figure 1. A) Abacus, B) balloon popping, C) Doorman, D) Plumber, E) car washing, F) matching, G) drumming

effects of a rehabilitation program planned according to functional status on physical and cognitive skills, considering the symptoms of both diseases in a patient with co-occurring MS and PD.

In recent years, virtual reality-based rehabilitation programs have become popular in MS and PD. In the systematic review study conducted by Porras et al. (17), it was revealed that virtual reality-based rehabilitation programs improved balance and walking in neurologic patient groups, including MS and PD. According to the study of Maggio et al. (18), which examined the effects of virtual reality on cognitive functions in patients with PD, it was concluded that virtual reality-supported rehabilitation could be an important tool for developing cognitive functions. Again, according to a review study conducted by Maggio et al. (4), virtual reality approaches developed cognitive and motor functions in patients with MS. When the results of our case report were analyzed, it was observed that balance and walking exercises improved mobility and that game therapy improved the cognitive functions and manual skills of the patient within the scope of the game-supported rehabilitation program. Allen et al. (3) divided

\begin{tabular}{|c|c|c|}
\hline \multicolumn{3}{|l|}{ Demographics } \\
\hline \multicolumn{2}{|l|}{ Age (year) } & 54 \\
\hline \multicolumn{2}{|l|}{ Sex } & Female \\
\hline \multicolumn{2}{|l|}{ Height $(\mathrm{cm})$} & 167 \\
\hline \multicolumn{2}{|l|}{ Weight (kg) } & 90 \\
\hline \multicolumn{2}{|c|}{ Body mass index $\left(\mathrm{kg} / \mathrm{m}^{2}\right)$} & 32.37 \\
\hline \multicolumn{2}{|c|}{ Dominant side (right/left) } & Right \\
\hline \multicolumn{2}{|l|}{ Education status } & Primary school \\
\hline \multicolumn{2}{|l|}{ Occupation } & Housewife \\
\hline \multirow{2}{*}{$\begin{array}{l}\text { Disease duration } \\
\text { (month) }\end{array}$} & MS & 168 \\
\hline & $\mathrm{PD}$ & 36 \\
\hline \multicolumn{3}{|c|}{$\begin{array}{l}\text { MS type Relapsing-remitting } \\
\text { cm: Centimeter, kg: Kilogram, m: Meter, MS: Multiple sclerosis, PD: Parkinson's } \\
\text { disease }\end{array}$} \\
\hline
\end{tabular}




\begin{tabular}{|c|c|c|c|c|}
\hline \multicolumn{3}{|l|}{ Clinical evaluations } & Before & After \\
\hline \multicolumn{3}{|l|}{ EDSS score (0-10) } & 8 & 7.5 \\
\hline \multicolumn{3}{|l|}{ Frequency of falling } & 1/week & None \\
\hline \multicolumn{3}{|l|}{ Rigidity (Left elbow and wrist) } & Moderate & Mild \\
\hline \multicolumn{3}{|l|}{$\begin{array}{l}\text { Lower extremity } \\
\text { Gross muscle strength }\end{array}$} & Weak & Moderate \\
\hline \multicolumn{3}{|l|}{ MoCA $(0-30)$} & 16 & 22 \\
\hline \multicolumn{3}{|c|}{ New York posture rating scale (0-85) } & 33 & 55 \\
\hline UPDRS & \multicolumn{2}{|c|}{ Treatment complications $(0-23)$} & 14 & 2 \\
\hline \multirow{3}{*}{ Fatigue impact scale } & \multicolumn{2}{|c|}{ Cognitive impact score $(0-40)$} & 35 & 18 \\
\hline & \multicolumn{2}{|c|}{ Physical impact score $(0-40)$} & 33 & 16 \\
\hline & \multicolumn{2}{|c|}{ Psychosocial impact score (0-80) } & 65 & 41 \\
\hline \multicolumn{3}{|l|}{ FIM (0-126) } & 63 & 87 \\
\hline \multicolumn{3}{|l|}{ PDQ-39 (0-100) } & 74.57 & 23.11 \\
\hline \multirow{2}{*}{ MSQOL-54 } & \multicolumn{2}{|l|}{$\begin{array}{l}\text { Physical score } \\
(0-100)\end{array}$} & 15.26 & 68.49 \\
\hline & \multicolumn{2}{|l|}{$\begin{array}{l}\text { Cognitive score } \\
(0-100)\end{array}$} & 17.67 & 81.04 \\
\hline
\end{tabular}

patients with PD into tablet based-exergame and control groups and evaluated patients' upper extremity functions at the end of 12 weeks to examine the effects of exergame. As a result of the study, it was found that although there was no improvement in upper extremity functions of patients who played exergames, speed increased in some upper extremity tests, which could reduce the accuracy of movement. According to this result, the authors emphasized the need to consider the specificity of task practice (3). In our case report, it is observed that game-supported rehabilitation, which evaluates upper extremity functions individually on the touch screen and runs motion patterns with different grip materials, improves upper extremity skills in individuals with cooccurring MS and PD. The reason for the development of upper extremity functions of the patient is thought to be the planning of the scenarios of the games used in rehabilitation in accordance with daily life activities. In this respect, rehabilitation implemented with the present game console provides an important advantage over game-supported rehabilitation examined in other studies. Ribas et al. (19) divided patients with PD into conventional treatment and game-supported conventional treatment groups and showed that the game-supported treatment programs differed significantly in balance functions and fatigue severity compared with conventional treatment programs. The results of other studies in the literature support the effects of game-assisted rehabilitation on functions and fatigue in a patient with co-occurring MS and PD.

\section{Conclusion}

In conclusion, when the literature is examined, many studies are indicating that virtual reality-based and game-supported rehabilitation approaches improve cognitive and motor skills in MS and PD. In our case report, it was revealed that gamesupported rehabilitation approaches in co-occurring MS and PD, which are rarely encountered in the clinic, improved motor and cognitive functions in the individual. In progressive neurologic diseases such as MS and PD, the rehabilitation process is long, and may even be lifelong. For this reason, game-supported approaches that increase the participation and motivation of patients in the rehabilitation process with feedback and make rehabilitation fun 
and efficient are extremely important in terms of increasing the result obtained from rehabilitation and improving the individual's functional independence in daily life. However, for generalization, individuals with co-occurring MS and PD should be screened more, included in rehabilitation programs, and treatment results should be evaluated with objective methods.

\section{Ethics}

Informed Consent: The patient and relatives were informed about the case report and written consent was obtained before starting.

Peer-review: Externally peer-reviewed.

\section{Authorship Contributions}

Concept: G.S., M.K., Design: M.K., Data Collection or Processing: G.S., Analysis or Interpretation: G.S., M.K., Literature Search: G.S., M.K., Writing: G.S., M.K.

Conflict of Interest: No conflict of interest was declared by the authors.

Financial Disclosure: The authors declared that this study received no financial support

\section{References}

1. McNamara P, Stavitsky K, Harris E, Szent-Imrey O, Durso R. Mood, side of motor symptom onset and pain complaints in Parkinson's disease. Int J Geriatr Psychiatry 2010;25:519-524.

2. O'Connor P. Key issues in the diagnosis and treatment of multiple sclerosis: an overview. Neurology 2002;59(Suppl 3):S1-S33.

3. Allen NE, Song J, Paul SS, et al. An interactive videogame for arm and hand exercise in people with Parkinson's disease: A randomized controlled trial. Parkinsonism Relat Disord 2017;41:66-72.

4. Maggio MG, Russo M, Cuzzola MF, et al. Virtual reality in multiple sclerosis rehabilitation: A review on cognitive and motor outcomes. J Clin Neurosci 2019;65:106-111.

5. Kurtzke JF. Rating neurologic impairment in multiple sclerosis: an expanded disability status scale (EDSS). Neurology 1983;33:1444-1452.

6. Hoehn SM. Hoehn and Yahr Scoring Scale. In: Armitage A (ed). A practical guide to parkinson's disease: diagnosis and management. New York Springer, 2017.
7. Doğan Mert CE, Ateş Y, Güngör M. Parkinson Hastalığında Ölçme ve Değerlendirme. İçinde: Kılınç Muhammed AYS (ed.) Nörolojik Fizyoterapi ve Rehabilitasyonda Ölçme ve Değerlendirme: Vize Yayıncılık; 2019:4575 .

8. Otman SA. Kas Kuvveti ve Değerlendirme Yöntemleri. İçinde: Otman AS (ed). Tedavi Hareketlerinde Temel Değerlendirme Prensipleri. Ankara: Pelikan Yayıncilık, 2014:120-195.

9. Nasreddine ZS, Phillips NA, Bédirian V, et al. The Montreal Cognitive Assessment, MoCA: a brief screening tool for mild cognitive impairment. J Am Geriatr Soc 2005;53:695-699.

10. Howley ET, Franks BD. Health fitness instructor's handbook. Champaign. IL: Human Kinetics 1992:18-20.

11. Fahn S. Unified Parkinson's disease rating scale. Recent development in Parkinson's disease. Vol 2. Florham Park, NJ. Macmillan Health Care Information 1987, pp.15 3-163, 293-304.

12. Fisk JD, Ritvo PG, Ross L, et al. Measuring the functional impact of fatigue: initial validation of the fatigue impact scale. Clin Infect Dis 1994;18(Suppl 1):S79-S83.

13. Linacre JM, Heinemann AW, Wright BD, Granger CV, Hamilton BB. The structure and stability of the Functional Independence Measure. Arch Phys Med Rehabil 1994;75:127-132.

14. Jenkinson C, Fitzpatrick R, Peto V, Greenhall R, Hyman N. The Parkinson's Disease Questionnaire (PDQ-39): development and validation of a Parkinson's disease summary index score. Age Ageing 1997;26:353-357.

15. Vickrey B, Hays RD, Harooni R, Myers LW, Ellison GW. A health-related quality of life measure for multiple sclerosis. Qual Life Res 1995;4:187-206.

16. Desrosiers J, Rochette A, Hebert R, Bravo G. The Minnesota Manual Dexterity Test: reliability, validity and reference values studies with healthy elderly people. Can J Occup Ther 1997;64:270-276.

17. Porras DC, Siemonsma P, Inzelberg R, Zeilig G, Plotnik M. Advantages of virtual reality in the rehabilitation of balance and gait: systematic review. Neurology 2018;90:1017-1025.

18. Maggio MG, De Cola MC, Latella D, Maresca G, Finocchiaro C, La Rosa G, et al. What about the role of virtual reality in Parkinson Disease's cognitive rehabilitation? Preliminary findings from a randomized clinical trial. J Geriatr Psychiatry Neurol 2018;31:312-318.

19. Ribas CG, da Silva LA, Corrêa MR, Teive HG, Valderramas S. Effectiveness of exergaming in improving functional balance, fatigue and quality of life in Parkinson's disease: A pilot randomized controlled trial. Parkinsonism Relat Disord 2017;38:13-18. 